\title{
Green Open Space Form/Morphology Characteristics Which Function Ecologically as Rain Water Absorber in Kalirungkut Subdistrict
}

\author{
Tisa Angelia ${ }^{1}$, Haryo Sulistyarso ${ }^{2}$, Eko Budi Santoso ${ }^{2}$
}

\begin{abstract}
Growth of development in Kalirungkut Subdistrict with the functioning of MERR IIC road since 2010 is rapidly happening. The rapid development took place in the areas of trade and services, settlements, and industry as well as education. The growth development that caused the land use change is not balanced with the availability of Green Open Space (GOS) which is adequate as ecological function of rainwater absorber, thus becoming one of the causes of flood/puddle in Kalirungkut Subdistrict. Green open space to absorb rain water is part of a green infrastructure that integrates with city drainage in the form of storage and water absorption. The purpose of this research is to identify the characteristic of green open space form / morphology as an ecological function of rainwater absorber in Kalirungkut Subdistrict, by looking at the existing research benchmarks, drawing the conclusions of the analysis and making it a guideline in the development of green open space of further absorbent rainwater. This study uses a comparative descriptive analysis method. The selection of descriptive-comparative analysis is conducted to describe the comparison of existing green open space with standardization and supporting theories in the provision and development of green open space as an ecological function of rainwater absorber based on the aspects of existing research. The result of this research is the characteristic of the form/morphology of Green Open Space as ecological function of rainwater absorber in Kalirungkut Subdistrict which consists of Green Open Space form which functioned as water body in the form of water retention, the availability of garden \& sports field, various types of vegetation and supporting material, Appropriate Green Open Space, and Absorption Ability of this type of land cover.
\end{abstract}

Keywords-Characteristics of Form/Morphology Of Green Open Space, Green Open Space, Rainwater Absorbing Green Open Space.

\section{INTRODUCTION}

Rapid urban growth leads to land-use changes and increased direct surface flows and reduced quantities of water seeping into soil in green open space (GOS), resulting in flooding or puddles retained on the ground [1]. The presence of green open space as a field capable of

\footnotetext{
${ }^{1}$ Tisa Angelia is with Department of Architecture, Faculty of Architecture, Design, and Planning, Institut Teknologi Sepuluh Nopember (ITS), Kampus ITS Sukolilo, Surabaya 60111, Indonesia. E-mail: tisaangelia78@gmail.com.

${ }^{2}$ Haryo Sulistyarso and Eko Budi Santoso are with Department of Urban and Regional Planning, Faculty of Architecture, Design, and Planning, Institut Teknologi Sepuluh Nopember (ITS), Kampus ITS Sukolilo, Surabaya 60111, Indonesia. E-mail: haryo.its@gmail.com; eko_budi@urplan.its.ac.id.
}

absorbing water into underground water carrier layers is necessary in a drainage system [2]. The drainage system supported by GOS is an environmentally sound drainage system.

Changes in the availability of green open space as an ecological function of rainwater absorber in supporting the development of Rungkut area as a residential area, trade and services, causing green open space is still not sufficient in an effort to create an environment that is free from floods/puddles, this can be seen from the presence of floods/puddles in the District of Rungkut, especially Kalirungkut Subdistrict. GOS located in Kalirungkut Subdistrict needs to be developed to meet the existing water absorption needs. The conditions of green open space, either as storage or water absorption, are not well maintained, not even available as per the existing standardization.

The development of Surabaya City, especially East Surabaya area has been growing rapidly in the past 7 years. Many changes can be seen from the development of development. One of the changes that can be seen from before the year 2010 along MERR IIC Road is dominated agricultural land and residential area, while the current number of settlements and buildings for more and more business [3]. Changes in the availability of green open space as an ecological function of water absorbers in supporting the development of Rungkut area as a residential area, trade and services, causing green open space is still inadequate in an effort to create an environment free of floods/puddles, this can be seen from the occurrence of floods/puddles in the District Rungkut. The existence of floods/puddles other than the rainfall factor in the rainy season, also because Rungkut area is the downstream area proper flow of 4 major rivers including the Wonokromo River, Wonorejo, Kebon Agung, and Perbatasan river and vulnerable areas related to the region including the area East Coast of Surabaya (Pamurbaya)[4].

Kelurahan kalirungkut which is part of the District Rungkut, has several areas of standing water. Dinas Binamarga dan Pematusan Kota Surabaya [5] explained that between the years 2011 to 2013 there are additional points of water puddle, from only 8 areas of puddle point to 10 areas of standing water in District Rungkut. The addition of the puddle point is also related to the extent, length and height of the puddles that are still slightly decreased, even no change at some point of standing water in the District of 
Rungkut until 2015. The water puddle is around 0.15 ha to 72 ha, long water puddle 40 minutes to 90 minutes, and water puddle from $4 \mathrm{~cm}$ to $30 \mathrm{~cm}$. Two areas of the highest value of puddles obtained from overlay research in Rungkut Sub-district explained that Rungkut Harapan and Tulus Harapan Residential in Kalirungkut Subdistrict has the potential to develop GOS as an ecological function of rainwater absorber. GOS development related to its function as a rainwater absorber is expected to be an alternative to reduce the existence of water in the area of Kalirungkut Sub-districts and Rungkut in general.

With the existence of water puddles related to GOS development as part of environmentally sound drainage system in Kalirungkut Subdistrict, it is desperately needed to study the identification of characteristic of GOS form/morphology which has potential to be developed as ecological function of rainwater absorber in Kalirungkut Subdistrict.

\section{LITERATURE REVIEW}

\section{A. Urban Drainage System}

Drainage has the functions necessary for the survival of urban life, especially with the rapid development of development that causes land use change. A good drainage in surface water control is an environmentally sound drainage that has the concept of developing rainwater retention facilities in the soil and associated with green open spaces. Environmentally sound drainage or ecofriendly drainage serves to absorb surface water into the soil that later also can increase the water content of the soil during the dry season [6]. Environmentally sound drainage in surface water control is as a perfume and surface water storage, with physical drainage form parameters.

Surface water control with municipal drainage can be done by structural method or surface water control building based on environmentally sound drainage, in which case green open space becomes part of it. The shape of surface water control building in the form of impregnation and surface water storage can be seen in table 1 .

TABLE 1.

BUILDING SURFACE WATER CONTROL FORM

\begin{tabular}{cl}
\hline \hline Surface Water Controller & Physical form \\
\hline \multirow{3}{*}{ Surface Water Surviving } & Trenches \\
& Absorption pond \\
& Infiltration wells \\
& Biopori aperture \\
\hline \multirow{2}{*}{ Surface Water Storage } & Pool regulatio \\
& Situ / Reservoir / Boezem \\
\hline \hline
\end{tabular}

\section{B. Green Open Space (GOS)}

Green Open Space also means as green areas in the form of city parks, urban forests, green trails on either side or in the middle of the road, riverbanks or railroads, the building of each of the functions included in the Building Border Line And Building Coefficient [7]. The space left in the city which is a big hole can not be categorized as an open space of the city. So in other words the open space of the city is the space between buildings that are planned for a particular function. The green open space as part of the open space can be distinguished by its ownership, which is a private green open space and a public green open space. The green open space of the city is also part of urban spatial arrangement that has function as a protected area. The city's green areas consist of city parks, green urban forest areas, green recreational areas of the city, green areas of sports activities, Green area of the yard [8]. Green open space has many benefits for a community environment, whether of its vegetation, of its form and of its ownership or of its typology.

\section{Tipologi RTH}

Hakim in Nurulaini Distinguish green open space based on its physical being Natural Green Open Space (Natural GOS) and Built in Green Open Space (Built-in GOS). GOS Natural/protected areas such as nature reserves, forests, agricultural areas and paddy fields, nature reserves, national parks. Meanwhile, built-in GOS that function as urban lungs, water absorption, pollution prevention, and flora protection, include recreational and sporting facilities, horticultural gardens, public cemeteries and parks. Built-in GOS and Natural GOS has an equally important role as a rainwater absorber seen from ecological patterns related to environmental degradation and depends on its urban spreading.

Green open space has its constituent elements, which are soft elements and hard elements. Soft elements are the vegetation forming GOS while the hard elements are the constituents of green open space outside vegetation. GOS that is ecological function is the GOS that has the characteristics of the forming elements that support the function of green open space as an ecological function, it can be measured from how the type of land cover, where the type of land cover can be vegetation and GOS supporting materials of pavement.

\section{Ecological Function of Green Open Space}

The role and presence of green open space are important components related to the quality of human life which includes quality in hydrological, ecological, health, aesthetic and recreational functions [8]. The function of green open space among others: 1) Ecological function, green open space can improve ground water quality, prevent flooding, reduce air pollution and micro climate regulator; 2) The socio-cultural function, the presence of green open space can provide function as a space of social interaction, recreation facilities and as a point center of city; 3) The architectural function, green open space can increase the value of the beauty and comfort of the city through the existence of city parks and green paths of city roads; 4) Economic function, green open space as the development of urban green tourism facilities that can bring tourists [9]. The provision of green open space that functions ecologically as a rainwater absorber has benefits to improve groundwater quality and reduce and even prevent the presence of surface water in urban areas. 
GOS-forming elements, is soft and hard elements, need to be continuously developed to fulfill their function as an ecological function of rainwater absorber based on the type of land cover corresponding to the ecological function. The development of green open space needs to pay attention to the water absorbing capacity of the green open space, which can be seen from its run-off coefficient. Thus, the function of green open space as an ecological rainfall absorber can be seen from the provision and development of green open space function as an ecological function of rainwater absorber. In this case the parameters of the provision of green open space as an ecological function is the extent of the building elements of green open space based on the existing standardization, while the parameter of the development of green open space ecological function is how the ability to absorb water type of land cover green open space existing.

\section{RESULTS AND DISCUSSION}

\section{A. Identification Analysis Of Characteristics Shape/Morphology Green Open Space As Ecological Function Of Rain Water Supply}

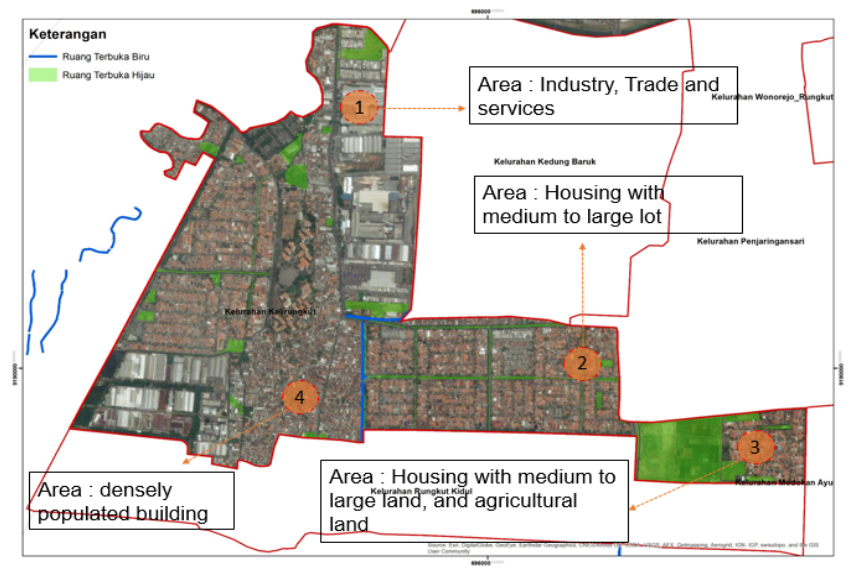

Figure 1. The division of study area in Kalirungkut sub-district by region

Internal aspects of research are derived from the study of theories derived from experts who are experts in their field. Comparative descriptive analysis is done by comparing the standardization and policies that support the application of these aspects in Kalirungkut Subdistrict as research area with existing condition of study area obtained from observation. The comparative descriptive analysis will be described in each aspect of the existing research based on several areas in Kalirungkut Sub-district.

\section{B. Aspects of Water Absorption and Surface Water Storage}

The condition of Water Absorption and water storage in Kalirungkut Subdistrict has not been sufficient as GOS functioned as the absorption or storage of rain water. The presence of other forms of water absorption or storage of water such as conservation ponds, River side polder as mentioned in Kementerian PU Cipta Karya [10] and RDTR UP. Rungkut, not available due to limited land. Provision of absorption wells which generally is a continuation of the presence of rainwater reservoirs, are not yet available and need to consider the ground water level as an area with 0 $1,5 \mathrm{~m}$ ground water level, and the location where the waterworks will be built. Biopori that has been applied in some housing, less functioning and useless.

The solid condition of the building for the provision of water control forms such as water containers can be used under the building, either independently or communally. The provision of the water control building requires awareness of the community residents in both the densely populated residential and residential areas. While good cooperation from the developers of housing, trade and service entrepreneurs is also needed in the provision of water control building. The use of trenches and rain gardens (bioretention) based on theory Halief [11], as small conservation ponds are more appropriate for this region due to groundwater and narrow area conditions for open space provision. While the use of biopori is considered less appropriate because of the absorption capacity is still less than the maximum in some housing.

The results of the analysis on the aspect of surface water control is Kalirungkut Subdistrict requires flood control building in accordance with geomorphological condition, local community and cooperation of trade and service entrepreneur, industry and housing developer. Availability of entrepreneurs and housing developers in the provision of rainwater control structures in the form of mini bozems that require large areas in public and private areas. It requires awareness of community densely populated residential and residential districts and other private GOS owners in the supply of absorbing wells with rain water catchment, trenches and rain gardens (bioretention) as green open space rainwater absorber.

\section{Aspects of Type of Built-in and Natural Green Open Space}

Conditions of built-in GOS and natural GOS owned Kalirungkut Subdistrict area still can not meet the requirements to be GOS good ecological function, as mentioned in RDTR UP. Rungkut is Green Garden City Park, 90\% must be greened and 10\% for the completeness of the park (walkway, park bench, ornamental pond, and other supporting buildings), Parking Area becomes part of $40 \%$ of land area that must be provided in recreation GOS, The developer of the Housing Zone is required to allocate $2 \%$ of the land for the development of the tomb and provide a green path corresponding to the treads of the local head, and protect the area along the GOS of certain functions such as along the SUTET, the river border by establishing a green and passive park.

The built-in GOS condition is inadequate active park, active park and green line is only $10,165 \mathrm{~m}^{2}$ from Kalirungkut Sub-District 147,33 ha, besides this area do not have urban forest, there is only small farm area. The existence of active parks or sports field either public or private is still little availability, but it also has no urban forest due to limited land. The existence of the tomb as built-in GOS is not entirely provided by the housing 
The $3^{\text {rd }}$ International Seminar on Science and Technology

August $3^{\text {rd }}$ 2017, Postgraduate Program Institut Teknologi Sepuluh Nopember, Surabaya, Indonesia

developers, as well as GOS river border condition is not maintained even can be said damaged. The existence of the parking lot has been in accordance with the provisions of each building, but the parking cover material needs to be considered to function as a good open space absorbent rainwater.

The analysis results on the built-in and natural type of GOS is natural GOS in this region can not be developed unless there is provision from the developers of housing, trade and service entrepreneurs such as hotels and education or citizens with local government. The built-in spaces such as parks and sports fields can be more easily developed with the participation of citizens in both densely populated and residential districts in the provision, as well as awareness from private parties such as housing developers and trade and service entrepreneurs.

\section{Aspects of Variety of Vegetation and GOS Support Materials}

The suitability of crop vegetation with the type of soil that existed in the District Rungkut based on the theory of Mulyanto (2013) consisting of rice crops (Oryza sativa L.), Corn (Zea mays L.), and cassava (Manihot utilissima) in accordance with alluvial soil conditions in Rungkut District, but can not be developed because it requires extensive land that is difficult to obtain in Rungkut District. Alluvial soil conditions also make land in this region can not be easily planted by large woody vegetation.

TABLE 2.

\begin{tabular}{|c|c|c|}
\hline $\begin{array}{l}\text { Type of } \\
\text { Vegetation }\end{array}$ & Characteristics & Conformity \\
\hline $\begin{array}{l}\text { Pine } \\
\text { (Pinus } \\
\text { merkusii) }\end{array}$ & $\begin{array}{l}\text { Large trees, straight rods, } \\
\text { cylindrical. In the sandy soil } \\
\text { the spread of roots reaches } 7 \\
\text { times the average height. In } \\
\text { the clay soil (fine texture) } \\
\text { the tree roots only spread } \\
\text { one and a half times the } \\
\text { average tree. }\end{array}$ & $\begin{array}{l}\text { Not in } \\
\text { accordance } \\
\text { with alluvial } \\
\text { soil conditions } \\
\text { of smooth } \\
\text { texture or clay }\end{array}$ \\
\hline $\begin{array}{l}\text { Teak } \\
\text { (Tectonia } \\
\text { grandis) }\end{array}$ & $\begin{array}{l}\text { The stem is round and } \\
\text { straight. Teak will grow } \\
\text { better on land with clay } \\
\text { fraction, sandy clay or sandy } \\
\text { clay. }\end{array}$ & $\begin{array}{l}\text { Less suitable } \\
\text { with alluvial } \\
\text { soil conditions } \\
\text { in the form of } \\
\text { clay }\end{array}$ \\
\hline $\begin{array}{l}\text { Mahogany } \\
\text { (Swietenia } \\
\text { macrophylla) }\end{array}$ & $\begin{array}{l}\text { Round stems, many } \\
\text { branching. Mahogany does } \\
\text { not have specific soil type } \\
\text { requirements, and grows } \\
\text { naturally in alluvial, } \\
\text { volcanic, lateric, and high } \\
\text { clay soil types. Mahogany } \\
\text { also thrives in the brackish } \\
\text { sands close to the beach. }\end{array}$ & $\begin{array}{l}\text { In accordance } \\
\text { with alluvial } \\
\text { soil conditions } \\
\text { and brackish } \\
\text { sand near the } \\
\text { coast. }\end{array}$ \\
\hline
\end{tabular}

In addition there are theories and standardization of the various types of vegetation that can store large amounts of water, puddle-resistant vegetation more than 40 days (high water content) or vegetation sources of raw water (around the coast), and the usefulness of vegetation grass and bamboo.
TABLE 3.

LARGE WATER STORAGE VEGETATION[13]

\begin{tabular}{ll}
\hline \hline Type of Vegetation & Characteristics \\
\hline Cangkring & Medium tree size, short stems, spiny, \\
occathrina fusca Lour) & $\begin{array}{l}\text { occionally up to 2m, can grow up to } \\
\text { 20m, grow in shallow water habitats }\end{array}$ \\
\hline Palm & The roots are tenacious, the stems are 60 \\
(Metroxylon sagu) & $\begin{array}{l}\text { cm in diameter, tall to 25 m tall, the } \\
\text { leaves are simple pinnate, the stalk is } \\
\text { very strong, widened at the base and } \\
\text { spiked sharp, capable of growing on } \\
\text { sandy soil or clay, can grow in swamp or } \\
\text { stream }\end{array}$ \\
\hline \hline
\end{tabular}

TABLE 4.

VEGETATION OF SOURCE OF RAW WATER[14]

\begin{tabular}{ll}
\hline \hline Name of Vegetation & Latin Name \\
\hline Sea Pines & Casuarina equisetifolia \\
Rubber Munding & Ficus elastica \\
Mangosteen & Garcinia mangostana \\
Bungur & Lagerstroemia speciosa \\
Coconut & Cocos nucifera \\
Resin & Agathis loranthfolia \\
Kiara Payung & Filicium decipiens \\
\hline \hline
\end{tabular}

TABLE 5.

CHARACTERISTICS OF GRASS AND BAMBOO VEgetATION[15]

\begin{tabular}{l} 
Grass \\
\hline \hline
\end{tabular}

The various types of GOS support materials in the form of a land cover pavement are part of the forming elements of the built-in GOS which are the hard elements of the Green Open Space. The supporting material has the ability to function as absorbing surface water, and depends on the type of material of each land cover.

TABLE 6.

CRITERIA FOR RAINWATER ABSORPTION OF SOME LAND COVER[10]

\begin{tabular}{ll}
\multicolumn{1}{c}{ Type of Land Cover } & $\begin{array}{c}\text { Ability to Avoid Seepage of } \\
\text { Rain Water }\end{array}$ \\
\hline \hline Asphalt road, concrete, etc. & $70 \%-95 \%$ \\
paving block & $50 \%-70 \%$ \\
grass block & $60 \%$ \\
The Road is Pebbly & $50 \%$ \\
Vegetation & $5 \%-15 \%$ \\
\hline \hline
\end{tabular}


Vegetation of tree species, shrubs, shrubs and grasses can be found in Kalirungkut Sub-District, as land that has been processed. Soil conditions have undergone processing from alluvial soils that have low permeability to soil that supports the growth of various vegetation. But the extent of land cover in the form of vegetation is still far from enough. Vegetation corresponding to alluvial soil conditions, such as mahogany, palm, jackfruit. Vegetation resistant to puddles such as teak trees until mahogany trees are found in this region. Likewise with raw water vegetation, green road vegetation paths of trees, shrubs, shrubs. The existence of the path of green road with its variety mostly less well maintained especially for vegetation shrubs and grass. Grass vegetation is not considered by the owners of buildings, especially in industrial buildings / factories, trade and services, and settlements. The use of pavements dominates as land cover because of the demand for space in the building. Basically the study area's soil conditions are suitable for agricultural and palawija vegetation.

The result of analysis on vegetation aspect and GOS supporting material is to determine the vegetation type which has the potential to be developed related to rain water absorption that is vegetation that has the ability to withstand the inundation and has a deep root system both in private area (yard) and public, such as: Large tree species with rooting into the soil of mahogany, cangkring, palm, loa tree, jackfruit and breadfruit. For near-shore areas are puddle-resistant vegetation such as sea pine, rubber munding, mangosteen, bungur, coconut, resin and kiara payung. In addition, vegetation cover land of bamboo and grass species. For shrub and bush vegetation, with soil management and water use in good care such as canna, japanese soka, puring, swords, ribbon lilies can grow well. As for the vegetation on the land of agriculture and palawija less appropriate because it requires a large area. Potential GOS support materials that are potentially developed in the study area are pavement pass water that can easily penetrate the ground water quickly, such as the use of gravel and grass block.

\section{E. Aspects of GOS Supply}

Based on the existing condition of GOS supply in the form of sub-reservoir [2], Where the Sub-Resevoir can be provided below or above the surface of the land with a predetermined area, has not been encountered in the study area. For narrow land the provision of sub-reservoirs can be placed under the building independently or made communally, by agreement of the local community. Provision of green open space as a whole as a function of rainwater absorber in the form of parks and sports fields, as mentioned in RDTR UP. Rungkut on the provision and necessity in maintaining the existence of private and public GOS, has not done well. GOS conditions are still not well maintained. Pavement materials as ground cover many use paving blocks and much reduce the presence of grass.

Overall, the existing condition of green open space availability as an ecological function integrated with drainage system (environmentally sound drainage) has not been found in the study area. This is because the lack of information citizens and the financial ability in implementing the drainage system. Provision of green open space with a population of 2015 of 25,347 people is needed about 100 units of good quality parks, while the number of parks in the study area is still 1 unit of park in Rungkut Asri Timur. The area of the park and the green line for the study area with the existing population should be $12,750 \mathrm{~m}^{2}$, but still available about $7,025 \mathrm{~m}^{2}$.

The result of analysis on the aspect of GOS provision is the provision of GOS is not yet sufficient as ecological function of rainwater absorbent in the study area, in terms of size, quantity and quality. So that the characteristics of GOS provision in the form of rainwater container with its supporting vegetation as a rainwater absorber has the potential to be developed in reducing the degradation of the environment.

\section{F. Aspect of Development GOS}

Green Open Space development as an ecological function of rainwater absorber based Permen PU No.12 Tahun 2014 about Penyelenggaraan Sistem Drainase Perkotaan, Perda No.12 Tahun 2014 Kota Surabaya, dan Juknis Perencanaan Sistem Drainase Perkotaan, Kementerian PU Cipta Karya 2014, not separated by the type of land cover and the ability to absorb water from the type of land cover. In addition, soil type also gives a great influence on the ability to absorb water from a green open space in a region. Each type of soil has different permeability. The soil type in this area is alluvial with the type of sandstone clay, silt and silt clay. The soil type is very suitable for agricultural crops and crops.

TABLE 7.

Criteria Value of Coefficient of SoIl Permeability SeVeral Land COVER[10]

\begin{tabular}{cl}
\hline \hline Type of Land Cover & Ability to Avoid Seepage of Rain Water \\
\hline Gravel & $>10 \mathrm{~cm} / \mathrm{det}$ \\
Sand & $10-0,01 \mathrm{~cm} / \mathrm{det}$ \\
Silt & $0,01-0,00001 \mathrm{~cm} / \mathrm{det}$ \\
Clay & $<0,00001 \mathrm{~cm} / \mathrm{det}$ \\
\hline \hline
\end{tabular}

Overall the existing condition of the study area has many different types of vegetation, from tree species, shrubs, bushes and grasses. There are also rice and corn crops. However, for trade and service buildings most do not provide tree vegetation or cover/grass, but cover green open space with pavement or GOS support material from rocks. Soil conditions have undergone much processing from low permeability alluvial soils to soils that can support the growth of various vegetation. But the extent of land cover in the form of vegetation is still far from enough. Vegetation suitable for alluvial soil conditions and puddle resistant such as mahogany, palm, jackfruit species; Types of land cover in the form of bamboo and grass vegetation can be found in the study area. The existance of grass vegetation in both public and private areas is not considered by the owners of buildings, especially in types of industrial buildings/factories, trade and services, and housing. The 
use of pavement still dominates because of the demand for space in the building. Basically the soil condition for the study area is a type of fertile soil suitable for agricultural and palawija vegetation.

The result of the analysis on the aspect of GOS development is that the existing green open space development must pay attention to the water absorption capacity or the level of soil permeability and the run-off coefficient of each land cover. Vegetation with the lowest run-off coefficient value has the potential to be developed in the study area to reduce the occurrence of standing water during heavy rain, and the GOS grass-supporting material that pass water such as grass block is very suitable to be developed. Alluvial soil types in the study area with sand and clay clay content, as well as silt geology and some areas are sand clays, should be considered in selecting the type of vegetation and the type of water impregnation to be developed. The development of tree species vegetation that has roots deep into the soil will be very good for giving cavities to the soil that multiply the water into the soil, such as mahogany trees that can live in clay or sandy clay. Based on the soil type, the development of green space that functioned as a water body in the form of bozem, retention pond or rain garden, trench catchment, very well developed in the Kalirungkut Sub-District, either communally or from self-help communities and entrepreneurs/developers of trade and services and housing there is.

G. Green Open Space Form/Morphology Characteristics which Function Ecologically as Rain Water Absorber

The analysis of characteristic aspects of GOS form/morphology that has the potential to be developed as an ecological function of rainwater absorber in Kalirungkut Subdistrict shows the presence of green open space that functioned as an absorbent and inadequate water storage is not even available. Variety of vegetation cover types of land has not been sufficient in fulfilling its function as ecological function and other functions of the green open space, as well as the selection of GOS-type supporting materials in the form of pavement which mostly still use waterproof cover. In addition, the development of rapidly developed land in this study area also resulted in aspects of natural green open space such as protected areas/national parks/urban forest also has limited land in the provision and development. Based on the analysis to see how the suitability between standardization and theory about the development of GOS of rainwater absorbent with existing condition of Kalirungkut Sub-District, the characteristic of GOS form/morphology which potentially developed as ecological function of rainwater absorber in Kalirungkut Subdistrict, are :

1. The development of a form of surface water control that can be applied in accordance with the geomorphological condition of Kalirungkut Sub-District, the form of flood control such as absorption pond/conservation pond/rain garden (bioretention), rainwater catchment with absorption wells and run-off channel, trenches, and small boezem.
2. Development of parks and sports fields.

3. Expand the rainwater catchment area with the use of ground cover in the form of grass and bamboo, multiplying the variety of tree vegetation, shrubs, bushes as inhibitors of surface water rates. Types of large trees with roots enter the soil and hold 40-day inundation such as mahogany, cangkring, palm, loa tree, jackfruit and breadfruit, sea firs, munding rubber, mangosteen, bungur, coconut, resin and kiara payung on the coastal area. For shrub and bush vegetation, vegetation types such as canna, japanese soka, puring, swordfish, ribbon lilies can grow well.

4. Development of agricultural land in an effort to maintain existing ones in conservation land.

5. The provision of green open space either below or above the surface of the soil according to the standardization of the laying of surface water control building, both in private and public space, and requires local community cooperation with government, trade and services, industry and housing entrepreneurs.

6. Development of land cover that has good rainfall absorption capability. Absorption capability to water is having a run-off coefficient of $0.05-0.15$ for vegetation cover and 0.50 - 0.60 for green open space support materials, such as the use of grass block, gravel.

\section{CONCLUSION}

The Green Open Space form/morphology which has the function as a rainwater absorber is needed as an effort to control the surface water that occurs in Kalirungkut Subdistrict. Characteristics of form/morphology is the most important form of water control in the form of Absorption ponds/conservation pond/rain garden (bioretention), rainwater catcher with absorption wells and runoff channels, trench catchment, and small boezem. In addition, the development of parks and sports fields, as well as maintaining agricultural land in the conservation area. The existence of the garden by expanding the vegetation such as mahogany, cangkring, palm, loa tree, jackfruit and breadfruit, and sea fir, rubber munding, mangosteen, bungur, coconut, resin and kiara payung on the area around the beach. For shrub and bush vegetation, vegetation types such as canna, japanese soka, puring, swordfish, ribbon lilies can grow well. The shape/morphology of the green open space needs to consider the location and standardization of its extent. Overall development of Green Open Space water absorbers need to consider the type of land cover that is able to easily absorb surface water, is vegetation and supporting materials in the form of grass block and gravel.

\section{ACKNOWLEDGEMENT}

Thanks to Mr. Haryo Sulistyarso and Mr. Eko Budi Santoso for his guidance. Acknowledgments also to all ranks of Dinas Kebersihan dan Ruang Terbuka Hijau Kota Surabaya, Bappeko Surabaya, Kalirungkut Sub-district, 
Academician, Developer of PT. YEKAPE, and Community Leaders in Kalirungkut Sub-district.

\section{REFERENCES}

[1] H. Mulya, J. Hadihardadja, and R. Kodoatie, "Small Islands Water Availability Analysis In Groundwater Basin (Gwb) And NonGroundwater Basin (Non-Gwb) Using Modified Mock Calculation Method," Int. Ref. J. Eng. Sci., vol. 2, no. 8, pp. 01-11, 2013.

[2] R. Pamekas, Pembangunan dan pengelolaan infrastruktur kawasan permukiman. Jakarta: PT Dunia Pustaka Jaya bekerja sama dengan Badan Penelitian dan Pengembangan, Kementerian Pekerjaan Umum (Balitbang PU), 2013.

[3] H. Purwadio, P. G. Ariastita, and H. Sulistyarso, "Pemintakan Kawasan Pengembangan Bangunan Tinggi Di Wilayah Surabaya Timur,” J. Penataan Ruang, vol. 9, no. 1, Jun. 2017.

[4] O. Vidianti and G. P. Ariastita, "Arahan Penataan Permukiman di Kelurahan Kalirungkut Surabaya,” Institut Teknologi Sepuluh Nopember, 2011.

[5] Dinas Binamarga \& Pematusan Kota Surabaya, Data Genangan Kota Surabaya 2010-2015. Surabaya: Dinas Binamarga \& Pematusan Kota Surabaya, 2016.

[6] A. Zulkifli, Pengelolaan kota berkelanjutan. Yogyakarta: Graha Ilmu, 2015.

[7] Direktorat Jenderal Penataan Ruang, Permen PU No: 05/PRT/M/2008 tentang Pedoman Penyediaan dan Pemanfaatan Ruang Terbuka Hijau di Kawasan Perkotaan. 2008.

[8] W. A. Rahmy, B. Faisal, and A. R. Soeriaatmadja, "Kebutuhan
Terbuka Kota, Kawasan Padat, Studi Kasus Wilayah Tegallega, Bandung,” J. Lingkung. Binaan Indones., vol. 281, no. 1, pp. 27-38, 2012.

[9] T. Lussetyowati, "Prosiding Seminar Nasional AVoER ke-3 Palembang A-10 ANALISA PENYEDIAAN RUANG TERBUKA HIJAU PERKOTAAN, STUDI KASUS KOTA MARTAPURA," in Seminar Nasional AVoER ke-3, 2011, pp. 195-207.

[10] Kementerian Pekerjaan Umum, Tata Cara Penyusunan Rencana Induk Sistem Drainase Perkotaan. Jakarta: Direktorat Jenderal Cipta Karya, 2012.

[11] K. Halief, R. D. P. Ningsih, and Nuryanto, "Pengembangan Teknik Bioretention dalam Mengatasi Limpasan Air Hujan," in Proceeding PESAT (Psikologi,Ekonomi, Sastra, Arsitektur \& Sipil), 2011, vol. 4.

[12] P. T. H. Budianto, R. Wirosoedarmo, and B. Suharto, "Perbedaan Laju Infiltrasi pada Lahan Hutan Tanaman Industri Pinus, Jati dan Mahoni,” J. Sumber Daya Alam dan Lingkung., vol. 1, no. 2, pp. 15-24, Jun. 2010.

[13] M. Ulfah, P. Rahayu, and L. Rossita Dewi, "Kajian morfologi tumbuhan pada spesies tanaman lokal berpotensi penyimpan air: Konservasi air di Karangmanggis, Boja, Kendal, Jawa Tengah," PROS SEM NAS MASY BIODIV INDON, vol. 1, no. 3, pp. 24078050, 2015.

[14] Pemprov Jatim, JUKNIS tentang Norma, Standar, dan Kriteria Pemanfaatan Ruang. Surabaya, 2015.

[15] D. Hartanto, "Konstribusi Akar Tanaman Rumput dan Bambu Terhadap Peningkatan Kuat Geser Tanah pada Lerengan,” J. Tek. Sipil, vol. 4, no. 1, pp. 39-49, 2007. 